\title{
ВЫДЕЛЕНИЕ ГРУПП ЗАПАСОВ И РЕСУРСОВ НЕФТИ И ГАЗА ПО КРИТЕРИЮ ЭКОНОМИЧЕСКОЙ ЭФФЕКТИВНОСТИ В НОВОЙ КЛАССИФИКАЦИИ ЗАПАСОВ И РЕСУРСОВ НЕФТИ И ГАЗА
}

Герт А.А., Вопкова К.Н., Супрунчик Н.А., Немова О.Г. (СНИИТГиМС, Новосибирск, Россия)

В 2005 году была принята новая российская Классификация запасов и прогнозных ресурсов нефти и горючих газов, в апреле 2007 года утверждены Методические рекомендации по ее применению'. Отличительной особенностью новой классификации является то, что помимо прежнего выделения категорий запасов и ресурсов по степени геологической изученности, в ней применяются принципы деления на категория и групाы по степени промышленной освоенности и экономической эффективности. В настоящей работе авторы описывают особенности выделения групп запасов и ресурсов нефти и газа в соответствии с новыми принципами.

Основным экономическия криперием выделения групп запасов нефти и газа по промышленной значимости и экономической эффективности является количественный показатель стоимостной оценки - величина чистого дисконтированного дохода, который может быть получен в результате эксплуатации объекта оценки (месторождения, залежи). Как вспомогательный показатель может использоваться внутренняя норма доходности.

На основе экономического критерия выделяют две группы запасов: промыцитенно значиные $и$ непромышленные.

Промыиитенно значимые запасы подразделяются на нормально-рентабельные (извлекаемые запасы месторождений (залежей), вовлечение которых в освоение экономически целесообразно и технически и технологически возможно с соблюдением требований по рациональному использованию недр и охране окружающей среды на момент оценки) $u$ ycловно-рентабельные (извлекаемые запасы месторождений (залежей), вовлечение которых в освоение может быть экономически целесообразным в ближайший временной период).

Понятно, что если месторождение разрабатывается или его вовлечение в освоение, согласно стоимостной оценке, может принести доход, его запасы относятся к нормально-рентабельными.

При определении условно-рентабельных запасов учитывается возможность появления благоприятных изменений в ценах реализации продукции, рынках сбыта и технологий. Такую возможность оценивают в рамках пятилетнего периода от текущего момента времени. При этом благогриятные изменения цен реализации продукции должны быть обоснованы коммерческими контрактами, либо прогнозами специализированных агентств. Отнесение запасов к группе условно рентабельных возможно, если имеются утвержденные графики строительства магистральных транспортных систем или обязательства компаний по развитию соответствующей инфраструктуры для добычи, подготовки и транспортировки углеводородного сырья. К условно-рентабельным относятся также запасы объекта оценки, который при автономном освоении является непромышленным, а оценка совместного освоения с близкорасположенными объектами позволяет получить положительный ЧДД.

К непромыииленнын запасам относятся запасы месторождений (залежей), вовлечение которых в разработку на момент оценки экономически нецелесообразно либо технически или технологически невозможно. В данную группу входят запасы нефти и горючих газов месторождений (залежей), которые экономически неэффективны для освоения на современном этапе, а также месторождения, расположенные в пределах водоохранных зон, населенных пунктов, сооружений, сельскохозяйственных объектов, заповедников, памятников природы, истории и культуры, и месторождения, значительно удаленные от транспортных путей и территорий с развитой инфраструктурой нефтедобычи. Выделение групшы непромышленных запасов по условиям недоступности и отсутствия реальных технологий разработки месторождений (залежей) осуществляется на основе качественной оценки невозможности их освоения.

Если на месторождении для целей классификации выделяется несколько объектов оценки (залежей, частей залежи), то стоимостная оценка проводится по каждому объекту. При этом, если по результатам оценки запасы хотя бы одного объекта относятся к промышленно значимым, то и месторождение относится к промыпленно значимым. Если на месторождении нет ни одного объекта с промышленно значимыми запасами, оно относится к непромышленным.

Основным экономическии критериел выделения групп ресурсов нефти и газа по промышленной значимости и экономической эффективности явяяется показатель ожидаемой стоиюости запасов - чистый дисконтированный доход, прогнозируемый по результатам будуших геологоразведочных работ с учетом вероятности их успеха и затрат на проведение.

Ресурсы по экономической эффективности подразделяются на две группы - рентаб́льные, имеющие положительную ожидаемую стоимость запасов, и неопределенно рентаб́льные, имеющие отрицательную ожидаемую стоимость запасов.
1 Разработка Классификации запасов и прогнозных ресурсов нефти и горючих газов и Методических рекомендаций по ее применению осушествлялась под руководством Г.А. Габриэлянца большим коляективом авторов, включая авторов настоящей статьи 